\title{
State Economic Entities in Modern Russian Airport Industry
}

\author{
Yakovlev A.Y.* \\ State University of Management, \\ Diplomatic Academy of the Ministry of Foreign Affairs of \\ the Russian Federation \\ Moscow, Russian \\ e-mail: gosypravlenie@yandex.ru
}

\author{
Titov A.A. \\ Gzhel State University \\ Electroizolyator, Russia \\ e-mail: andrew.magistr.ggu@ yandex..ru
}

\begin{abstract}
The Russian Federation is the largest country in the world. It has a significant number of hard-to-reach areas and territories to which a year-round access is possible only by aircraft. Despite the importance of the theme of Russian transport there aren't many scientific articles on this topic. State economic entities do not often become an object of scientific research. That is why the current theme is actual. This article is devoted to the analysis of the role and place of state economic entities in modern Russian airport industry. As a result of the study, the following tasks were solved: location, existing forms of ownership, organizational types and main types of economic activities of economic entities in Russian airport industry were analyzed; the place of state economic entities in mentioned sphere was identified. In the Russian Federation there are the following main types of state economic entities in airport industry: joint-stock companies, official duty enterprises and state budgetary institutions. There are some differences between those types related on the part of the country. In the Central Russia there are no public joint-stock companies or budgetary institutions; in Russian North-West there is a public joint-stock company and budgetary institution; in the south of the country only $10 \%$ of the regions airport economic entities are limited liability companies, but in Central Russia $35 \%$. In general, most economic entities in modern Russian airport industry are joint-stock companies.
\end{abstract}

Keywords - state economic entity, state company, state jointstock company, company with state participation, airport, airport industry, airports in Russia.

\section{INTRODUCTION}

Nowadays the Russian Federation faces many tasks in the socio-economic and socio-political spheres. Much of it lies in the economic sphere.

One of the main tasks is to restart economic processes in the country. To do that Russian authorities should develop the transport system of the country.

The Russian Federation is a large country with a significant number of hard-to-reach areas. For example, a trip from Moscow to Vladivostok is about $9000 \mathrm{~km}$ and takes more than 6 days or the way from Moscow to Murmansk lasts 1.5-2 days and is $2000 \mathrm{~km}$ long. There is great numbers of cities where there are no railways and the only way to get there is by aircraft. Among them are region capitals (Magadan, Anadyr, etc.). That is the reason why the government has to develop all kinds of transport. Special attention is paid to aviation. It makes it possible to move rapidly people and goods throughout and outside the country. To make it possible, Russia should have an extensive airport network throughout the country.

For this and related purposes has been adopted the State program "Development of the transport system" for the period 2018-2024. Also there is a federal project "Development of regional airports and routes".

In these documents one of the priorities is to increase the level of economic connectivity of the territory of the Russian Federation. One of the measures is the reconstruction of the infrastructure of airports and the expansion of the network of interregional regular passenger air routes.

The airport industry in Russia on the current moment is far from ideal. However, the reconstruction of airport infrastructure depends largely on who is its owner. Not every airport owner has available resources to make investments in developing. That is why the issue of the ownership of the airport is critically important.

\section{PROBLEM STATEMENT}

Russia and its economy have many distinctive features. The main one is that the country started to build market economy only about 30 years ago. In the former USSR all property except personal property till 1991 belonged to the Soviet state. Russia historically has a large public sector. It was before and after the Soviet period. Despite the years of privatization, country remains a large public sector which increased in the last decade.

Among the state property there are companies with state participation [2], state unitary enterprises, different types (budgetary, official duty and autonomous [18]) of state industries [4], etc.

Despite huge public sector, it does not become a subject of analysis of Russian scientists. There is a rather small number of research directly devoted to this issue. More often there are studies about different aspects (legal status [7], strategy [4], tax planning [10]) of management for companies in general $[5,9,12,14]$ or problems of public administration [13] and state policy [6].

Also in Russia it is possible to find research on transport sphere [11].

Foreign researchers do not have big interest in Russian state economic entities. But there are a lot of studies on the issue of corporate governance in other countries $[8,15]$. 
Mentioned research gap is one of the main reasons why introduced subject is actual and important.

To achieve current research goal authors have chosen the methodology based on general scientific methods. Among them are analysis, synthesis, comparison, induction, deduction, etc. The authors also applied systemic, modeling and other methods.

\section{RESULTS}

For a more accurate naming of the object of study, we will reveal the basic categories "airport", "operator of the airport" and "airport industry".

According to the Air Code of the Russian Federation, an airport is disclosed as "a complex of structures, including an aerodrome, an airport terminal and other structures designed to receive and departure aircraft, operate air transportation and have the necessary equipment for these purposes" (Clause 3, Article 4 [16])

The operator of the airport is an economic entity of various organizational and legal forms. It owns an aerodrome or heliport of civil aviation and operates it in order to ensure take-off, landing, taxiing and parking of civil aircraft (Clause 2 of Article 49 [16]).

In turn, the airport industry should be understood as an industry that implements a set of transport and technological processes for receiving and departure of aircraft, servicing the air transport.

After the designation of the main categories, we shall now move straight to the analysis of airports.

As an object of study the authors took airports of federal significance, assigned to such an order of the Government of the Russian Federation of 20.04.2016 №726-r and analyzed: their location, legal forms, entities acting as founders or participants, and their shares and main activities.

Now lets see where federal airports are located and there basic characteristics.

For our analyses we have chosen 4 of 8 federal districts which are located in different parts of Russia. We have chosen Northwest, Central, Ural and South federal district (table 1).

TABLE I. BASIC CHARACTERISTICS OF NORTHWEST, CENTRAL, URAL AND SOUTH FEDERAL DISTRICTS

\begin{tabular}{|l|l|l|l|l|l|}
\hline \multirow{2}{*}{ Basic characteristics } & \multicolumn{4}{|c|}{ Federal district } & \multirow{2}{*}{ Total } \\
\cline { 2 - 5 } & $\begin{array}{c}\text { North- } \\
\text { west }\end{array}$ & Central & Ural & South & \\
\hline Number of regions & 11 & 18 & 6 & 8 & 43 \\
\hline $\begin{array}{l}\text { Territory, million sq } \\
\text { km }\end{array}$ & 1.7 & 0.6 & 1.8 & 0.4 & 4.5 \\
\hline Population, million & 14 & 39.4 & 12.4 & 16.5 & 82.3 \\
\hline $\begin{array}{l}\text { Gross regional } \\
\text { product, billion US\$ }\end{array}$ & 123.9 & 385.2 & 148.5 & 77.7 & 735.3 \\
\hline Number of airports & 11 & 14 & 10 & 10 & 45 \\
\hline $\begin{array}{l}\text { Number of region } \\
\text { capitals without } \\
\text { federal airport }\end{array}$ & 1 & 6 & 0 & 2 & 9 \\
\hline
\end{tabular}

\footnotetext{
a. Elaborated by authors
}

As we can see from table 1, Russian federal districts have huge differences. The number of regions in federal districts differs much (the biggest amount of regions is in Central federal district, the lowest number is in Ural federal district). Central federal district also is the richest and the most populated. Unfortunately for the local population, only $2 / 3$ of the south regions have airports. On the other hand, in Ural federal district all the regions have airports. The biggest number of airports again is in Central federal district. Moscow has 4 (Domodedovo, Ostafyevo, Sheremetyevo and Vnukovo international airports) of 18 airports of the federal district. If we add to them Zhukovsky International Airport which is situated in Moscow region, the amount of airports in Moscow agglomeration will be 5 or $35.7 \%$ of central Russia airports.

If we try to find connections between Gross regional product and number of airport or population and number of airport we will fail. In Ural and South federal region are 10 airports, but Gross regional product of Ural federal region is twice bigger. The population of Ural federal district is higher too.

Regional transport networks are also different. The territory of South federal district 4.5 and 4.25 times smaller than Ural federal district, but the number of airports is the same.

Of considerable interest is the question of who owns airports (table 02).

TABLE II. FORMS OF OWNERSHIP OF RUSSIAN FEDERAL AIRPORTS IN NORTHWEST, CENTRAL, URAL AND SOUTH FEDERAL DISTRICTS

\begin{tabular}{|l|l|l|l|l|l|}
\hline \multirow{2}{*}{$\begin{array}{c}\text { Forms of } \\
\text { ownership }\end{array}$} & \multicolumn{4}{|c|}{ Airports in federal district } & \multirow{2}{*}{ Total } \\
\cline { 2 - 5 } & North-west & Central & Ural & South & \\
\hline $\begin{array}{l}\text { Russian } \\
\begin{array}{l}\text { Federation } \\
\text { (federal } \\
\text { property) }\end{array}\end{array}$ & 0 & 1 & 1 & 2 \\
\hline $\begin{array}{l}\text { Regions } \\
\text { (regional } \\
\text { property) }\end{array}$ & 6 & 6 & 2 & 1 & 15 \\
\hline Mixed & 1 & 2 & 2 & 0 & 5 \\
\hline Private & 4 & 6 & 5 & 8 & 23 \\
\hline Total & 11 & 14 & 10 & 10 & 45 \\
\hline
\end{tabular}

The structure of ownership quite differs. The biggest amount of regional property is in Northwest and Central federal districts, the lowest - in South federal district. The Russian Federation has only 2 airports - Elista Airport in the capital of the Republic of Kalmykia and International Airport Magnitogorsk in important industrial city of Chelyabinsk region. In federal property there are also shares of Vnukovo International Airport (25\%) and Sheremetyevo International Airport (30\%).

In private property there are important transport airline hubs: Domodedovo International Airport (Moscow) and regional capitals airports (Kaliningrad International Airport, Yekaterinburg International Airport, Chelyabinsk International Airport and Tyumen International Airport, etc.). 


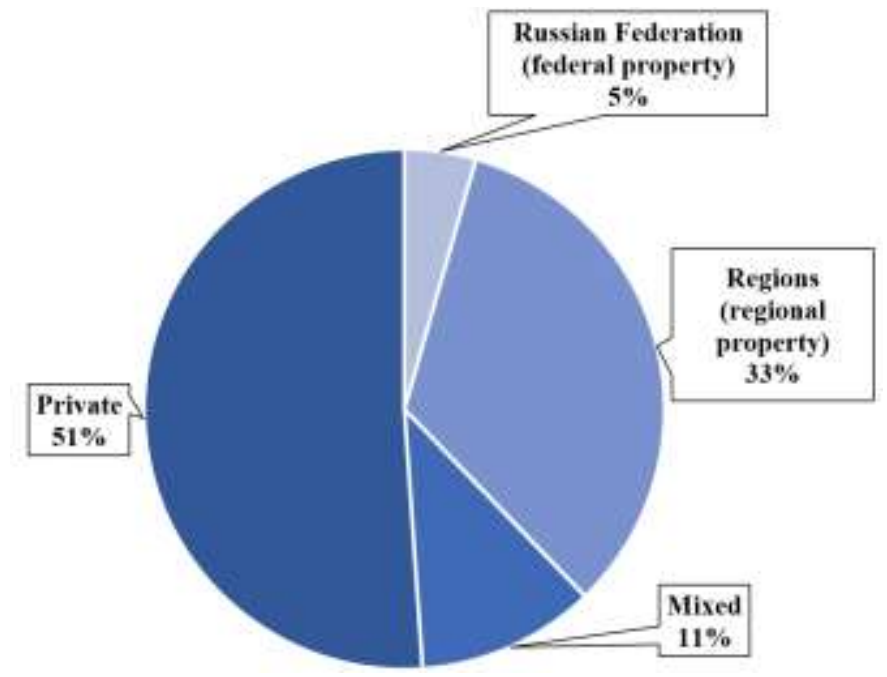

Fig. 1. Owners of Russian federal airports in Northwest, Central, Ural and South federal districts

The situation in general in 4 federal districts is the following. In private property is $51 \%$ of airports. Also private persons and organizations have shares in $11 \%$ of airports. The Russian Federation has total control only in $5 \%$ of airports. Regions are the only owner in $1 / 3$ of airports.

A were interesting situation is with organizational types of Russian federal airports (table 03).

TABLE III. ORGANIZATIONAL TYPES OF RUSSIAN FEDERAL AIRPORTS IN NORTHWEST, CENTRAL, URAL AND SOUTH FEDERAL DISTRICTS

\begin{tabular}{|l|l|l|l|l|l|}
\hline \multirow{2}{*}{$\begin{array}{l}\text { Organiza- } \\
\text { tional types }\end{array}$} & \multicolumn{4}{|c|}{ Airports in federal district } & \multirow{2}{*}{ Total } \\
\cline { 2 - 5 } $\begin{array}{l}\text { Public joint- } \\
\text { stock } \\
\text { company }\end{array}$ & 1 & 0 & 1 & 2 & 4 \\
\hline $\begin{array}{l}\text { Joint-stock } \\
\text { company }\end{array}$ & 7 & 7 & 8 & 7 & 29 \\
\hline $\begin{array}{l}\text { Limited } \\
\text { liability } \\
\text { company }\end{array}$ & 2 & 5 & 1 & 1 & 9 \\
\hline $\begin{array}{l}\text { Official duty } \\
\text { enterprise }\end{array}$ & 0 & 2 & 0 & 0 & 2 \\
\hline $\begin{array}{l}\text { State unitary } \\
\text { enterprise }\end{array}$ & 0 & 0 & 0 & 0 & 0 \\
\hline $\begin{array}{l}\text { State } \\
\text { budgetary } \\
\text { institution }\end{array}$ & 1 & 0 & 0 & 0 & 1 \\
\hline Total & 11 & 14 & 10 & 10 & 45 \\
\hline
\end{tabular}

In all federal districts there is organizational type of jointstock company. There are 4 public joint-stock companies (PJSC “Airport Murmansk", PJSC “Airport Koltsovo", OJSC "Anapa Airport" and PJSC "Volgograd International Airport"). If we add to joint-stock companies limited liability companies, there will be $9 / 10$ of the airports of Northwest, Central, Ural and South federal districts with organization type "company".

One of the reasons of choosing a joint stock company by the Russian Federation and regions is the simpler and quicker procedure for their procurement of goods, works and services
[17]. Airport industry is not the only sphere with companies with state participation.

The Russian Federation is the official shareholder (participant) of about 1000 companies. Among them PJSC Sberbank, VTB Bank (PJSC), PJSC "Rostelecom", PJSC Rosseti, PJSC Gazprom, PJSC NK Rosneft, PJSC "United Aircraft Corporation", JSC United Shipbuilding Corporation, etc. Russian regions are owners of more than 2000 companies.

There are also 2 official duty enterprises in Central federal district and a budget institution in Northwest federal district.

State enterprise of Kursk region "Kursk International Airport" and the regional state official duty enterprise "Lipetsk International Airport" are not the only official duty enterprises in the Russian Federation. There are more in other federal districts. For example, Federal official duty enterprise "Amderma Airport", Federal official duty enterprise "Kyzyl Airport", State official duty enterprise of the Kuril Islands "Airports of the Kuril Islands" and State official duty enterprise of the Chuvash Republic "Cheboksary Airport". As we can mention, there are federal and regional official enterprises.

Budgetary institution of the Republic of Karelia "Petrozavodsk Airport" which is situated in Northwest region is not the only budgetary institutions in Russia. For example, there is Tambov regional state budgetary institution "Tambov Airport", State budgetary institution of Ryazan region "Regional Airport "Protasovo", State budgetary institution of Penza Region "Airport of the City of Penza", State budgetary institution of the Republic of Mari-El "Airport Yshkar-Ola", State budgetary institution the Republic of Mordovia "Saransk International Airport".

There is a great variety in the names of airports, but there is always designation of the owner (Russian Federation or region).

It is important to mention, that one official duty enterprise or budgetary institution can't be at the same time in federal and regional property.

In the given sample, there are no airports - unitary enterprises, but they are represented in other regions of the country. For example, there is a state unitary enterprise of the Amur Region "Blagoveshchensk Airport", State unitary enterprise of the Orenburg region "Airport Orenburg", and State unitary enterprise of the Yamal-Nenets autonomous area "Tarko-Sale Airport").

In Russia not only the Russian Federation and regions can be public owners of airports. Some municipalities have shares in joint-stock companies or are owners of other organizations. In Ural federal district in JSC "Surgut Airport" $19 \%$ of stokes belong to Surgut city. Airport has a stable financial and economic situation. The reason why airport is developing is its location in one of the main oil cities of rich Russian region (Khanty-Mansiysk autonomous area - Ugra).

There are other examples in the country. In the Republic of Khakassia there is a municipal enterprise of air transport "Shira Airport", the founder of which is the municipality of Shirinsky district. For a number of reasons, the organization is 
in an extremely difficult situation. Some time ago, the municipal unitary enterprise "Bereznik Airport" (founder of Vinogradovsky district of Arkhangelsk region) and the Kargopol municipal district municipal unitary enterprise "Kargopol Airport" (Arkhangelsk region) liquidated in 2003 and 2009.

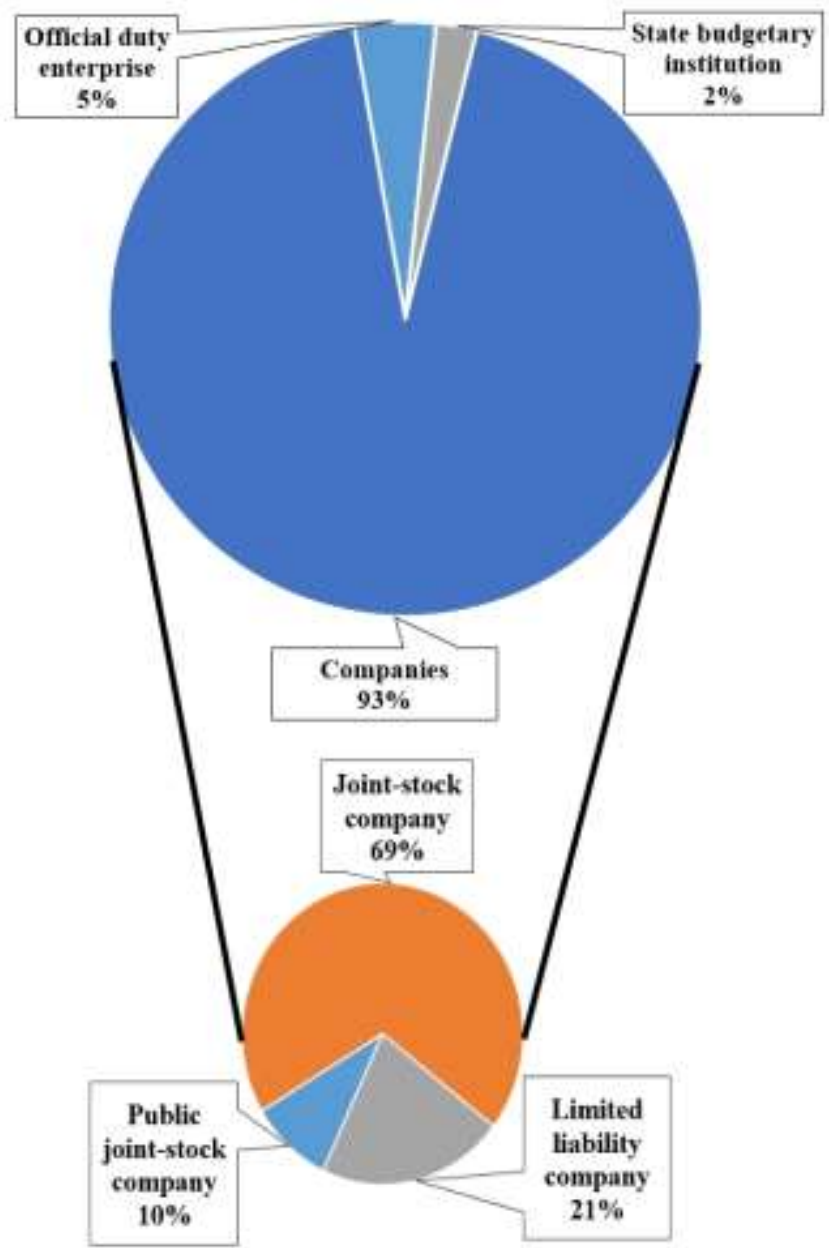

Fig. 2. Organizational types of Russian federal airports in Northwest, Central, Ural and South federal districts

As we can see (figure 02), $93 \%$ of Northwest, Central, Ural and South federal districts federal airports are companies and only $7 \%$ the other organizational types.

In addition to the organizational types, airports differ in their main activities.

The main type of activity of organizations was determined according to what they indicated during state registration of economic entities in accordance with the All-Russian Classifier of Types of Economic Activities (table 04).

Displaying the table data in the graphical form, we obtain the following.

The most airports have the main type of economic activity "airport activities" (51\%). In other airports the main types are "scheduled air passenger transportation" (18\%), "auxiliary activities related to air and space transport" (16\%) "other auxiliary activities related to air transport" (9 \%). Some airports have an exotic main type of economic activity like "non-scheduled air cargo transportation" (2 \%) Nizhnevartovsk International Airport, "non-scheduled air passenger transportation" (2\%) - Vologda Airport, "activities of passenger air transport" (2\%) - Syktyvkar International Airport.

TABLE IV. MAIN TYPE OF ECONOMIC ACTIVITY OF RUSSIAN FEDERAL AIRPORTS IN NORTHWEST, CENTRAL, URAL AND SOUTH FEDERAL DISTRICTS

\begin{tabular}{|c|c|c|c|c|c|}
\hline \multirow{2}{*}{$\begin{array}{c}\text { Main type of } \\
\text { economic } \\
\text { activity }\end{array}$} & \multicolumn{4}{|c|}{ Airports in federal district } & \multirow[t]{2}{*}{ Total } \\
\hline & $\begin{array}{c}\text { North- } \\
\text { west }\end{array}$ & Central & Ural & South & \\
\hline $\begin{array}{l}\text { Airport } \\
\text { activities }\end{array}$ & 4 & 7 & 6 & 6 & 23 \\
\hline $\begin{array}{l}\text { Other } \\
\text { auxiliary } \\
\text { activities } \\
\text { related to air } \\
\text { transport }\end{array}$ & 0 & 2 & 1 & 1 & 4 \\
\hline $\begin{array}{l}\text { Scheduled air } \\
\text { passenger } \\
\text { transportation }\end{array}$ & 3 & 3 & 1 & 1 & 8 \\
\hline $\begin{array}{l}\text { Auxiliary } \\
\text { activities } \\
\text { related to air } \\
\text { and space } \\
\text { transport }\end{array}$ & 2 & 2 & 1 & 2 & 7 \\
\hline $\begin{array}{l}\text { Non-scheduled } \\
\text { air cargo } \\
\text { transportation }\end{array}$ & 0 & 0 & 1 & 0 & 1 \\
\hline $\begin{array}{l}\text { Non-scheduled } \\
\text { air passenger } \\
\text { transportation }\end{array}$ & 1 & 0 & 0 & 0 & 1 \\
\hline $\begin{array}{l}\text { Activities of } \\
\text { passenger air } \\
\text { transport }\end{array}$ & 1 & 0 & 0 & 0 & 1 \\
\hline Total & 11 & 14 & 10 & 10 & 45 \\
\hline
\end{tabular}

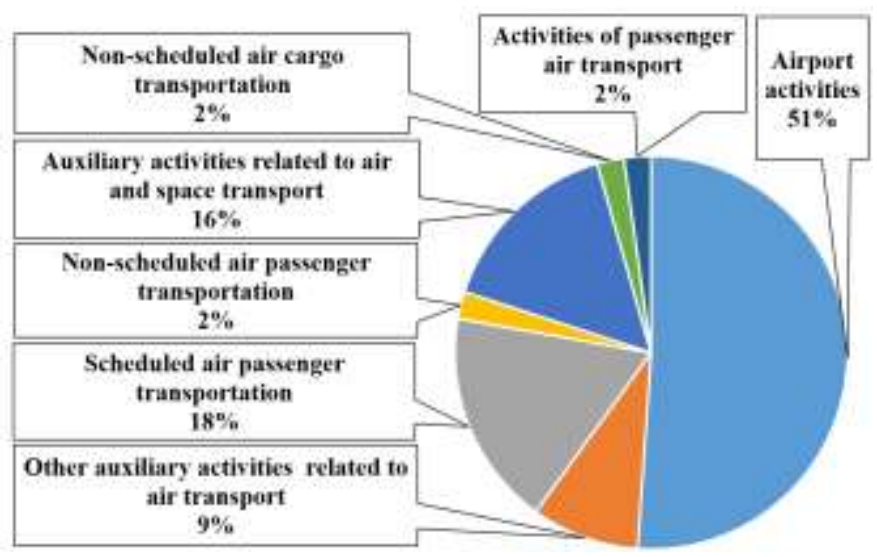

Fig. 3. Main types of economic activities of Russian federal airports in Northwest, Central, Ural and South federal districts

During the study, various approaches to management of airports and an airport network were identified. We consider these directions in more detail.

1. Managing own airport network. The example is JSC "Komiaviatrans". All its stocks belong to the Komi Republic. This company is the owner of Syktyvkar Airport, Airport 
Ukhta, Vorkuta Airport, Usinsk Airport, Ust-Tsilma Airport, Inta Airport and Pechora Airport. The Komi Republic does not have a company for each republic airport and it decided to concentrate all airport actives in one state joint-stock company.

2. Managing own airport and air fleet. For example, LLC Avia enterprise "Gazprom Avia". This company is the owner of Ostafyevo International Airport (Moscow), Bovanenkovo Airport and Yamburg Airport (Yamalo-Nenetsk autonomous area). The air fleet of the company is represented by more than 30 aircraft and more than 100 helicopters. Mostly the air routes are from Moscow to cities of Yamalo-Nenetsk autonomous area. The sole shareholder is PJSC Gazprom which is controlled by the Russian Federation.

3. Horizontal oriented management carried out by various economic entities performing various aspects of airport activities and subordinated to the airport operator. This management approach is shown in the activities of such an airport operator as Domodedovo Commercial Services LLC (Moscow). There is no state property in this limited liability company.

4. Managing of airport operators (companies) through management organization which is also a shareholder or a participant in dependent economic entities (airports). For example, Novaport LLC, Basel Aero LLC, Airports of the Regions JSC and Northern Capital Gateway. Novaport LLC is the owner of JSC "Chelyabinsk Aviation Enterprise", JSC "Airport Astrakhan", JSC "Volgograd International Airport", JSC "Airport Roshchino", PJSC "Airport Murmansk", JSC "Khrabrovo Airport". Basel Aero LLC manages OJSC "Anapa Airport”, JSC "International Airport Sochi”, JSC "Krasnodar International Airport".

5. A personal interest in effective management of the top management of the airport caused by the presence of a significant share in the company. This trend is observed with Ramport Aero JSC (operator of Zhukovsky International Airport).

\section{CONCLUSION}

Summing up, we note that nowadays the airport sector in Russia consists of economic entities of various organizational and legal forms, which are owned by the Russian Federation and subjects of the federation as well as by private individuals and municipalities. The latter as founders of airports are extremely rare. The most widespread among airports are jointstock companies.

The participation of the Russian Federation and subjects of the federation in such an important industry as the airport helps to increase the level of economic security and ensure the socio-economic development of the country with a large number of inaccessible settlements, as well as to solve existing and emerging problems in transport sphere.

For the Russian Federation it is very important who really controls airport industry as well as a structure and separation of powers [3]. That is why research on this theme is extremely important.

Russia has a huge and interesting experience which might be useful for other countries around the world.

\section{References}

[1] G. Butkovskaya, E. Sumarokova, "Digital strategies of companies: growth potential and reasons for failure", E-Management, vol. 2, no. 3, pp. 48-57, Retrieved from: https://doi.org/10.26425/2658-3445-2019-3-48-57

[2] Corporate management level. Informational and educational portal in state and municipal management, Retrieved from: http://gimyrf.ru/corporativnyj_uroven/, last acessed 12.02.2020.

[3] R.D. Grebnev, "Judicial power in the structure of the state mechanism and separation of powers", The Soc. Sci., vol. 11, iss. 22, pp. 5309-5313, 2016.

[4] I.I. Kokhanovskaya, Y.V. Nazarenko, "Financing of capital investments by budgetary and autonomous institutions: modern tendencies", Upravlenie, vol. 6, no. 2, pp. 4-9, 2018, Retrieved from: https://doi.org/10.26425/2309-3633-2018-2-4-9

[5] N.N. Kudryavtseva, Y.V. Pakhomova, Y.N. Duvanova, "The concept of management development management enterprise", Proc. of Voronezh State Univer. of Engineer. Technol., vol. 81, no. 1, pp. 429-433, 2019, Retrieved from: https://doi.org/10.20914/2310-1202-2019-1-429-433

[6] E.B. Lenchuk, "Course on new industrialization: A global trend of economic development", Studies on Russ. Econ. Development, vol. 27, iss. 3, pp. 332-340, 2016, Retrieved from: https://doi.org/10.1134/S1075700716030102

[7] O.A. Makarova, "Legal status of public joint-stock companies", Vest. SPbSU. Law, vol. 8, iss. 4, pp. 411-420, 2017, Retrieved from: https://doi.org/10.21638/11701/spbu14.2017.403

[8] B. Mees, S.A. Smith, "Corporate governance reform in Australia: a new institutional approach", British J. of Manag., vol. 30, iss. 1, pp. 75-89, Retrieved from: https://doi.org/10.1111/1467-8551.12298

[9] V.N. Narizhny, "To the question about improvement of profit formation management of the enterprise", Proc. of Voronezh State Univer. of Engineer. Technol., vol. 81, no. 1, pp. 485-491, 2019, Retrieved from: https://doi.org/10.20914/2310-1202-2019-1-485-491

[10] V.Y. Padalkin, G.N. Strukov, A.M. Prygunkov, L.I. Churikov, "The impact of tax planning on the level of economic security of the company", Proc. of Voronezh State Univer. of Engineer. Technol., vol. 81, no. 2, pp. 383-386, 2019, Retrieved from: https://doi.org/10.20914/2310-1202-2019-2-383-386

[11] V.A. Persianov, A.A. Stepanov, T.M. Gainochenko, "Research methodology and management on transport: main issues at the final stage of Russian transport sector reforms", Upravlenie, vol. 6, no. 3, pp. 11-16, 2017, Retrieved from: https://doi.org/10.26425/2309-3633-2018-3-60-65

[12] D.A. Shageev, T.A. Chuhonceva, "Universal rapid method of assessment and management decision-making of situational problems in the enterprise", Proc. of Voronezh State Univer. of Engineer. Technol., vol. 81, no. 2, pp. 359-376, 2019, Retrieved from: https://doi.org/10.20914/2310-1202-2019-2-359-376

[13] I.I. Smotritskaya, S.S. Shuvalov, "Development of the government procurement institution (toward the formation of a new model for the contract procurement system)", Econ. and Soc. Changes: Facts, Trends, Forecast, vol. 10, iss. 5, pp. 99-114, 2017.

[14] G.H. Stonehouse, N.Y. Konina, "Management Challenges in the Age of Digital Disruption". Advan. in Econ., Busin. and Manag.t Res., vol. 119, pp. 1-6, 2020, Retrieved from: https://doi.org/10.2991/aebmr.k.200201.001

[15] A.Z. Tayibnapis, L.E. Wuryaningsih, R. Gora, "Companies in Indonesia in the vortex of global economic disruption", Advan. in Soc. Sci. Ed. and Human. Res., vol. 308, pp. 174-177, 2019, Retrieved from: https://doi.org/10.2991/insyma-19.2019.45

[16] The Air Code of the Russian Federation of 19.03.1997, no. 60-FZ, Retrieved from: http://www.consultant.ru, last acessed 12.02.2020.

[17] A. Yakovlev, "Theoretical and practical aspects of managing Russian companies with state participation", The Europ. Proc. of Soc. \& Behavioural Sci. EpSBS, vol. LXXVI, pp. 3376-3382, 2019, Retrieved from: https://doi.org/10.15405/epsbs.2019.12.04.453

[18] A.Y. Yakovlev, "Features of management and implementation of financial and economic activities of various forms and types of institutions", Upravlenie, vol. 6, no. 4, pp. 55-61, 2018, Retrieved from: https://doi.org/10.26425/2309-3633-2018-4-55-61 